\title{
Beyond The Annals of Murder: The Life and Works of Thomas M. McDade
}

\author{
Jennifer L. Behrens ${ }^{\star \star}$
}

Thomas M. McDade is best known for his seminal 1961 reference bibliography of early American murder trials, The Annals of Murder. This article examines McDade's fascinating life and varied career as an early FBI agent, World War II veteran, corporate executive, and true crime chronicler, and compiles an annotated bibliography of McDade's lesser-known writings.

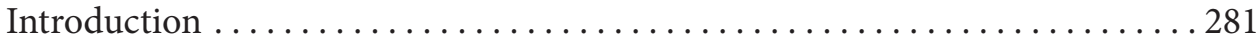

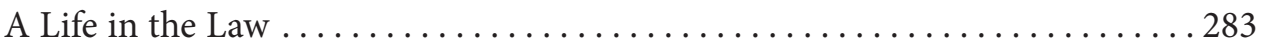

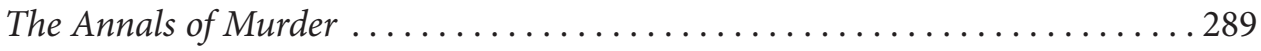

After the Annals ......................................... 292

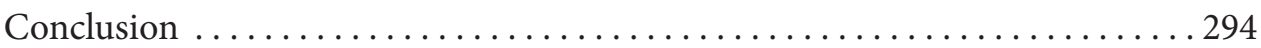

Appendix: Thomas M. McDade: An Annotated Bibliography . . . . . . . . . . 296

\section{Introduction}

I1 Defined at common law as "the unlawful killing of another human being with 'malice aforethought,"' criminal homicide has historically varied in its degree structure and punishment scheme. ${ }^{2}$ More constant, however, is Americans' seem-

* C Jennifer L. Behrens, 2019. This is a revised version of the winning entry in the Open Division of the 2018 AALL/LexisNexis Call for Papers Competition. I am grateful for all of the assistance that I received with sources and background information for this project, especially from Rachel Gordon at Duke Law School; the staff at Duke's Rubenstein Rare Book and Manuscript Library and UNC's Wilson Special Collections Library; Sharon Clasen at the Society of Former Special Agents of the FBI; Tanya Hollis at San Francisco State University's Labor Archives and Research Center; MaryAnna Schaefer and Ellen Gamber at St. John's University School of Law; Renee Pappous at the Rockefeller Archive Center; Patterson Smith; and Jared McDade. This article is dedicated to the memory of Dick Danner, Professor of Law Emeritus at Duke Law School, who provided invaluable editorial comments in the months before his passing.

** Associate Director for Administration and Scholarship, J. Michael Goodson Law Library, Duke University School of Law.

1. Model Penal Code $\$ 210.2 \mathrm{cmt} .1$ at $13-14$ (1985).

2. Model Penal Code $\$ 210.2 \mathrm{cmt}$. 2 at 16. Pennsylvania adopted the earliest American statutory degree classification for homicide in 1794, designed to restrict capital punishment to only firstdegree murder. Id.; see also 1793 Pa. Laws 607 (1794). 
ingly endless fascination with murder: in religious teachings; ${ }^{3}$ in literature; ${ }^{4}$ and particularly in scholarship, where numerous authors have attempted to quantify and seek patterns in the American homicide rate. ${ }^{5}$ As one such researcher noted, the severity of the crime and its punishment establishes "a potent reason for the intensive study of all the conditions and circumstances that produce criminal homicides ... . in order to discover how to prevent such crimes and how to deal effectively with those who commit them." 6 Others find a more philosophical reason to explore the depths of human cruelty: "to understand murder is to understand ourselves, in that we all share at least the capacity to destroy ourselves and each other."7

I2 Although homicide statistics and the stories behind them remain a researchers' gold mine, detailed studies can be stymied by incomplete or hard-to-find data, ${ }^{8}$ requiring the acceptance of "statistical generalization, meaning that it is 'mostly' or 'typically' true, but not always." Legal historians who wish to tell the stories behind the trials encounter similar research challenges: the sheer volume of unpublished trial orders; ${ }^{10}$ the difficulty in locating and consulting individual trial-level case records; ${ }^{11}$ and the amount of archival materials that have been lost to fires, floods, or history. ${ }^{12}$ But while "[c]omplete American trials are very hard to come by," one author noted in the 1960s, detailed accounts of criminal trials were commonplace in the nineteenth century. In the early years of America, a cottage industry of

3. See, e.g., Irene Merker Rosenberg \& Yale L. Rosenberg, "Cain Rose Up Against His Brother Abel and Killed Him”: Murder or Manslaughter?, 30 GA. J. INT'L \& CoMp. L. 57 (1986) (applying modern American and Jewish legal theory to Old Testament story of Cain slaying his brother Abel).

4. See, e.g., Carl Darryl Malmgren, Anatomy of Murder: Mystery, Detective, and Crime Fiction (2001); Zipora Wagner, Secular Understanding and Shattering the Myth of the American Dream: A Chronological Analysis of Changing Attitudes and Depictions of Murder within the Twentieth-Century American Literary Canon (Aug. 2011) (unpublished Ph.D. dissertation, Georgia State University) (on file with author).

5. See, e.g., H.C. Brearley, Homicide In the United States (1932) (reviewing nationwide data on homicide in the early 20th century); Randolph Roth, American Homicide 8-14 (2009) (noting historical fluctuation in American murder rates); Marvin E. Wolfgang, Patterns In Criminal HOMicide (1958) (analyzing five years of homicide data in Philadelphia).

6. Thorsten Sellin, Foreword, in WolfGANG, supra note 5, at xiii.

7. Roger Lane, Murder in America: A History 4 (1997).

8. See John Godwin, Murder U.S.A.: The Ways We Kill Each Other 6-7 (1978) (noting that crime statistics were not gathered at the national level until 1900, and not reliably until the FBI began its crime report series in 1933).

9. LANE, supra note 7, at 6.

10. Steven M. Barkan et al., Fundamentals of Legal Research 41 (10th ed. 2015) (noting small minority of state trial opinions that are published). Trial outcomes that are appealed to an intermediate appellate court and/or court of last resort will generate a record on appeal. This record generally includes selected case materials from the trial court, improving discoverability for researchers. See Kent C. Olson, Principles of Legal Research 293 (2d ed. 2015).

11. W.N. Davis, Jr., Research Uses of County Court Records, 1850-1879: And Incidental Intimate Glimpses of California Life and Society Part I, 52 CAL. Hist. Q. 241, 242 (1973).

12. See Olson, supra note 10, at 294 n.29 (noting the multiple fires that destroyed many of the earliest U.S. Supreme Court case materials); Rотн, supra note 5, at xii (estimating that attempting to derive murder statistics from court records alone "can be too low by a third or more, especially during wars or revolutions"); Ross E. Cheit, The Elusive Record: On Researching High-Profile 1980s Sexual Abuse Cases, 28 Just. Sys. J. 79, 80-84 (2007) (surveying records-retention policies of state criminal trial records).

13. Afterword, in The Quality of Murder; Three Hundred Years of True Crime 254 (Anthony Boucher ed., 1962). 
pamphleteers kept citizens informed-and entertained-with lurid details of the day's most sensational murder trials.

\3 For researchers who seek access to early American murder trial coverage, one source has provided reliable entry points to this literature for more than half a century: Thomas M. McDade's seminal 1961 bibliography, The Annals of Murder. ${ }^{14}$ Describing 1126 pamphlets and books on the subject of more than 600 individual murder trials dating from 1630 to 1900 , each numbered entry summarizes a pamphlet or book on a particular trial, along with publication and reprint information and the occasional editorial description by McDade. Equal parts legal sage (one case "proving again that you can get away with murder if you claim to be defending the American home") ${ }^{15}$ and wicked humorist ("There was a talking parrot in one of the murder rooms, but no one tried to interrogate the bird"), ${ }^{16}$ McDade's exhaustive research and pithy annotations provided book collectors and historians alike with an eminently readable catalog of early American murder trial accounts.

I4 While Thomas M. McDade will always be rightfully recognized for what one New Yorker contributor called "The Indispensable Guide to Early American Murder," ${ }^{17}$ his additional publications are far less well known. For more than four decades, McDade contributed regularly to journals and magazines on far-flung topics: true crime literature, naturally; but also book collecting, law enforcement, accounting, and Sherlock Holmes minutiae, to name a few. This article attempts to compile his body of work into an annotated bibliography and examines McDade's fascinating life and varied career as an early FBI agent, World War II veteran, corporate executive, and true crime chronicler.

\section{A Life in the Law}

I5 What led Thomas M. McDade to become an expert on early American murder trials? His path was somewhat surprising. McDade was born on July 2, 1907, to parents John McDade and Emma Thieme. ${ }^{18}$ He was raised in Brooklyn, New York, and grew up with two brothers: John Jr. and Paul. ${ }^{19}$ Young Thomas likely developed an early interest in both writing and crime: an area newspaper featured a poem about a juvenile delinquent by a "Thomas McDade (Age 11)," as part of a special section written by local youth in $1919 .{ }^{20}$ Despite the morbid subject matter of his

14. Thomas M. McDade, The Annals of Murder: A Bibliography of Books and Pamphlets on American Murders from Colonial Times to 1900 (1961) [hereinafter Annals].

15. Id. at 193 (Daniel McFarland).

16. Id. at 280 (William E. Sturtivant).

17. Casey N. Cep, The Indispensable Guide to Early American Murder, New Yorker: PAGETuRNER (June 22, 2016), http://www.newyorker.com/books/page-turner/the-indispensable-guide-to -early-american-murder [https://perma.cc/KP5V-MSNS].

18. City of New York Dep't of Health, Certificate \& Record of Birth No. 5785 (granted July 14, 1909) (on file with author). His mother's name is misspelled as "Tieme" on McDade's birth certificate, although the family spelling was “Thieme." See Obituaries, Brooklyn DAILy EAgle, May 3, 1934, at 17 (death notice of Mrs. J. Ulrricke Thieme, described as mother of Emma McDade and grandmother of Thomas).

19. John McDade Services, Brooklyn Daily EAgle, Oct. 19, 1932, at 3. Thomas was the middle child. See Fourteenth Census of the United States, 1920. (NARA microfilm publication, roll T625_1159). Records of the Bureau of the Census, Record Group 29. National Archives, Washington, D.C.

20. Thomas McDade, Bad Little Johnny, Brooklyn Daily EAgLe, Oct. 12, 1919, at JE7. While the 
earliest known publication, Thomas appears to have enjoyed an idyllic Brooklyn childhood, participating in the Boy Scouts of America ${ }^{21}$ and playing baseball. ${ }^{22}$

I6 After finishing high school, McDade attended City College of New York, graduating with a degree in accounting; he then enrolled in law school at St. John's. ${ }^{23} \mathrm{McD}$ ade seemed to thrive as a law student, winning a scholarship prize for the top grade in equity ${ }^{24}$ and serving as president of the school's Phi Delta fraternity. ${ }^{25} \mathrm{He}$ was also active in the law review, publishing a number of student notes and book reviews. ${ }^{26}$ He graduated cum laude with an LL.B. in $1931^{27}$ and was inducted into the school's Philonomic Council honor society. ${ }^{28}$ A local newspaper listed McDade among Brooklyn's successful New York State bar exam-takers in August $1931 .{ }^{29}$ He then continued his law studies at St. John's, completing an LL.M. degree in 1932, during which time he also served as vice president of the postgraduate class. ${ }^{30}$ McDade continued to work throughout his law studies: first as an accountant with Drehler Ore Casting Company, and then as an auditor at Brooklyn Edison Company. ${ }^{31}$

I7 Despite his bar exam passage in August 1931 and his LL.M. graduation in June 1932, McDade was not admitted to practice before the New York State bar until $1933,{ }^{32}$ a delay perhaps related to his older brother John's death in October 1932. ${ }^{33}$ Following his admission to the New York bar, McDade worked briefly in 1933 as a law clerk and legal editor. ${ }^{34}$ Eventually, he wrote a personal letter to J. Edgar Hoover, seeking work with the U.S. Department of Justice's Bureau of Inves-

publication lacks confirming details like a local address, the neighborhood and timeline generally fit (although McDade would have actually been 12 by the time of publication).

21. Official News by Brooklyn Scribes of Scout Meetings and Activities, BrookLyn Daily Eagle, July 13, 1919, at 29.

22. Classified ad, Brooklyn Daily Eagle, Apr. 25, 1920, at 79. Twelve-year-old McDade wished to trade his "slightly used" catcher's glove for a "baseman's mit [t] in the same condition."

23. Patterson Smith, Thomas McDade and The Annals of Murder, 97 AB BоокмAN's WkLY., Apr. 22, 1996, at 1613, reprinted at http://www.patterson-smith.com/mcdadeart.htm [https://perma.cc /G4W9-YYX7].

24. 731 Degrees are Conferred by St. John's, Brooklyn Daily EAgLe, June 12, 1930, at 17.

25. St. John's Coll. Sch. OF LAW, The Liber 197 (1931).

26. The total number is six, although the two earliest pieces were published under the name "Thomas E. McDade" and the later articles under the name "Thomas M. McDade." St. John's law school commencement programs and yearbooks from the era contain no other references to "Thomas E. McDade." The St. John's registrar's office contains a single grade card for Thomas McDade, where a typewritten middle initial "E." has been crossed out and corrected with a handwritten "M." Email from Mary-Anna Schaefer, Dir. of Annual Giving, St. John's University School of Law, to author (July 24, 2017, 9:04 EDT) (on file with author). Area newspapers also contained some references to "Thomas E. McDade" in Brooklyn, some matching the home addresses of Thomas M. McDade's father. Taken together, it is clear that Thomas E. and Thomas M. McDade were the same person.

27. St. John's Coll. Sch. of LaW, Fourth Annual Commencement Program 8 (June 10, 1931).

28. St. John's Coll. Sch. of LaW, The Liber 132 (1932).

29. Many Brooklyn Students Among 834 Passing Bar Out of Class of 2,167, Standard Union, Aug. 19,1931 , at 14. Although the variant "E." middle initial reappears here, the home address listed next to McDade matches the residence listed for his father in Brooklyn city directories of the time.

30. St. John's Coll. Sch. of LaW, The Liber 121 (1932).

31. Email from Jared McDade to author (Nov. 8, 2017, 12:51 PM EST) (on file with author).

32. 1 Martindale-Hubbell LaW Directory 1406 (1941) (listing McDade's year of admission as '33).

33. John McDade Services, supra note 19, at 3.

34. Email from Jared McDade, supra note 31. 
tigation. ${ }^{35}$ McDade joined the Bureau as a special agent in July 1934, training until September alongside 29 other classmates at the Munitions Building in Washington, D.C. ${ }^{36}$ During his time as an FBI agent, he specialized in investigating cases of bank robbery and kidnapping. ${ }^{37}$

I8 McDade maintained a pocket diary during his four years in the FBI, which is now believed to be "the only known diary of a Depression-era FBI agent." 38 The brief entries provide a rare first-person window into the daily life of 1930s G-men: late-night poker games and stakeouts with fellow agents, ${ }^{39}$ setting up and reviewing wiretaps, ${ }^{40}$ and interrogating suspects. ${ }^{41}$ The journal also paints a picture of the isolation in McDade's life-working for months at a time without talking to his family; ${ }^{42}$ spending Christmas with fellow agents; ${ }^{43}$ reviewing books, movies, and plays he'd taken in. ${ }^{44}$

19 While McDade's journal entries are generally quick reflections on his day's work, the wry and observant voice that he would later employ in the Annals shines through. For example, after several unsuccessful days looking for a suspect in every Chicago hospital, McDade "[s]pent balance of evening looking for new apartment and stole soap from all those visited." 45 Later, McDade reflected on having his tarot cards read by a fortune-telling suspect: "She read my fortune getting nothing right. When she asked me to take a wish, I wished we could convict her of the extortion. Later she told me I would get my wish." 46

\$10 McDade was personally involved in several high-profile cases as a field agent, most notably the 1934 apprehension of gangster "Baby Face" Nelson ("A day

35. Richard Liebson, Diary Details Life of Depression-Era "G-Man," JournaL News (Westchester County, N.Y.) (Jan. 10, 2014, 9:24 PM), https://www.usatoday.com/story/news/nation/2014/01/10 /diary-details-life-of-depression-era-g-man/4425363/ [https://perma.cc/M7HC-PEZE]. The Bureau of Investigation changed its name in 1935 to the Federal Bureau of Investigation. See U.S. Dep'T of Justice, The FBI: A Centennial History, 1908-2008, at 24 (2008).

36. Tom McDade, McDade Tells About '34 Training Class, GraPevine, June-July 1954, at 16. McDade would have undergone an extensive background check, several rounds of interviews, and the grueling weeks-long training course. See The Story of the FBI: The Official Picture History of the Federal BuREau of InVESTigation 31-35 (1947).

37. Thomas M. McDade, Sherlock Holmes and the F.B.I., Ellenry Queen's Mrstery Mag., Feb. 1957, at 96.

38. Society for Former Special Agents of the FBI, Transcript of Thomas M. McDade's Journal (Thomas L. Frields ed.) (unpublished manuscript) (on file with author) [hereinafter McDade Journal]; Liebson, supra note 35. The diary was donated to the National Law Enforcement Museum in Washington, D.C., which opened to the public in fall 2018. See Nat'L Law Enforcement Museum, https:// lawenforcementmuseum.org/ [https://perma.cc/NK54-8U74].

39. McDade Journal, supra note 38 (entry for Nov. 9, 1934).

40. Id. at Jan. 3, 1936 ("Much mean[n]ess and little good is shown in people from a telephone tap. I can see how often people lie, often unnecessarily.... I have yet to hear one person who sounds wholeheartedly honest.").

41. Id. at Feb. 7, 1935 ("[W] hen he lied on several questions he was pushed about a bit then finally admitted the truth"). McDade would later be suspended for 15 days after the suspect complained to the press about his beating by the interrogating agents. Two other agents were asked to resign. Id. at Feb. 19-27, 1935.

42. Id. at Feb. 1, 1935 (telephoning his parents for "the first time since Sept 1st").

43. Id. at Dec. 23-24, 1935.

44. Id. at Jan. 10-13, 1936. McDade praised John O'Hara's Butterfield 8 and Sinclair Lewis's It Can't Happen Here; Ed Bell's novel Fish on the Steeple fared less well ("of the Caldwell-Faulkner-Wolfe school though not nearly so good").

45. Id. at Nov. 14, 1934.

46. Id. at May 28, 1936. 
I will never forget," begins the journal entry). ${ }^{47} \mathrm{McD}$ ade spotted the fugitive's car on a Wisconsin highway and became the driver in a harrowing high-speed chase, first pursuing Nelson's car, then being pursued by Nelson while accomplice John Paul Chase fired a machine gun at the agents. ${ }^{48}$ The chase left two other agents, as well as Nelson, mortally wounded. ${ }^{49}$ McDade also participated in the 1935 Florida shootout that killed Kate "Ma" Barker and her son Fred. ${ }^{50}$

I11 After postings to numerous field offices, McDade was eventually transferred to a supervisory position at Bureau headquarters in Washington, D.C. His assignments included managing the Miscellaneous Desk, where agents sorted through any citizen complaints that did not fit one of the Bureau's other investigatory categories. (McDade would later reflect on this experience in a 1978 essay, whose title was drawn from the agency's nickname for this department: “The Nut Letter Desk.") ${ }^{51}$ McDade left the Bureau in 1938, although he remained active in the Society of Former Special Agents of the FBI, an alumni organization. ${ }^{52} \mathrm{He}$ reflected on his FBI experiences in several later publications, beginning with a 1949 piece in the Dun \& Bradstreet magazine Dun's Review, in which he tracked down members of his 1934 training class and reported on their current whereabouts. ${ }^{53}$

I12 Occasionally, McDade’s former life as a G-man caught up with him in other strange ways. When John Paul Chase, a member of Baby Face Nelson's gang who had been part of that fatal pursuit, came up for parole in the 1950s, McDade expressed no objection to his release, a position that displeased J. Edgar Hoover. ${ }^{54}$ In 1968, a short biographical sketch of McDade's career appeared in Who's Who in CIA, an East German compilation of 3000 current and former U.S. government employees alleged to be operatives of the Central Intelligence Agency. ${ }^{55}$ In the

47. Id. at Nov. 27, 1934.

48. Thomas M. McDade, Looking for Baby-Face, in The Vintage Car Murders 96, 99-100 (Jonathan Goodman ed., 1988).

49. U.S. DeP'T OF Justice, supra note 35 , at 31.

50. McDade Journal, supra note 38, at Jan. 16, 1935 (noting that the Barkers "had fired about 150 shots from 2 tommys, a 33 Winchester rifle and a .45 Colt automatic which had been shot out of [Ma’s] hand").

51. Thomas M. McDade, The Nut Letter Desk, in I, Witness: Personal EnCounters with Crime By Members of the Mystery Writers of America 301-12 (Brian Garfield ed., 1978). In his earlier days as a field agent, McDade had complained in his journal of such missives: "Wonder why Bureau wastes money chasing persons who write one threatening letter for over a year when it is obviously the work of a crank.” McDade Journal, supra note 38, at July 7, 1935.

52. Soc'y of Former Special Agents of the Fed. Bureau of Investigation, Membership DirecTORY, Jan. 1, 1949 (listing McDade as chairman of the group's Public Relations Committee). McDade was approved for membership of the Society in November 1938. New Members Admitted, GraPEVINE, Christmas 1938, at 3 .

53. Thomas M. McDade, The Most Carefully Selected Men in the World, Dun's Rev., May 1949, at 19. This article sparked internal memoranda within the FBI, although officials noted that it was "very commendatory." Office Memorandum from Louis Nichols to M.A. Jonas (May 20, 1949) (on file with author). The typed memo contains a handwritten note reading "I regret to see this maverick outfit [presumably the Society, which had helped McDade compile the article] cashing in on the real FBI." Id. A later internal memo attributed this comment to J. Edgar Hoover himself. Memorandum to Louis Nichols 5 (Jan. 8, 1954) (on file with author).

54. Smith, supra note 23, at 1614 . In his journal, McDade had noted the agents' sympathy for Chase at the time of his arraignment: "Most of the fellows, including myself, feel sorry for him as he seems to have been merely a tool in Nelson's hands. He said that Nelson bawled him out for not shooting us when they were along side." McDade Journal, supra note 38, at Dec. 31, 1934.

55. Julius Mader, Who's Who in CIA; eIN BIOGRAPhisches NaChSChlageWerk üBer 3000 
1970s, McDade also corresponded with former Barker gang associate Alvin "Creepy" Karpis, who had decamped to Torremolinos, Spain, following his release from Alcatraz. McDade tracked him down and arranged a two-day meeting there in 1978 , where the pair discussed their shared history. ${ }^{56}$

I13 After leaving the FBI, McDade reentered private law practice. ${ }^{57} \mathrm{He}$ married art school graduate Beatrice Clifford in 1940; their wedding announcement noted his employer as the New York law firm Bigham, Englar, Jones, and Houston. ${ }^{58}$ In 1942, McDade joined the U.S. Army, eventually achieving the rank of lieutenant colonel. His expanding family relocated to Washington, D.C., in 1943, where his wife Beatrice and firstborn son Jared lived during McDade's overseas military assignment. $^{59}$

I14 McDade would later describe his service during World War II as "two years in the South Pacific, moving from Australia, New Guinea and the Philippines up to Japan." 60 While stationed in the Philippines, his prior experience in law enforcement undoubtedly aided his assignment to help reorganize the Manila police department. ${ }^{61} \mathrm{McDade}$ left an impression on the country's court system as well, playing a small role in a 1949 opinion from the Supreme Court of the Philippines. ${ }^{62}$ He ultimately received a Bronze Star for his military service. ${ }^{63}$

I15 After returning to civilian life, McDade joined the General Foods Corporation as an accounting manager in $1946 .{ }^{64}$ Beatrice McDade and four-year-old Jared left Washington in April to join him in their new home in Rye, New York. ${ }^{65}$ Daugh-

MitARBeITER DER ZIVILEN UND MILITÄRISCHEN GEHEIMEDIENSTZWEIGE DER USA IN 120 STAATEN 344 (1968). McDade's entry lists his date of birth, his years of service in the FBI and U.S. Army, and his then-current position at General Foods. All of the information is correct (aside from the overarching insinuation that $\mathrm{McD}$ ade was also an active CIA operative). The CIA would later retaliate against this Stasi-backed publication by aiding journalist John Barron in the compilation of a list of known KGB agents, which appeared in the appendix of his book, KGB: The Secret Work of Soviet SECret Agents (1974).

56. See Thomas M. McDade, Karpis Recalls His Crime Spree of 1930s in Talks with McDade, Grapevine, May 1980, at 36; Smith, supra note 23, at 1614-16.

57. Liebson, supra note 35.

58. Clifford-McDade Bridal Planned for March 16, Brooklyn DaIly EAGLE, Mar. 9, 1940, at 4. The alumni newsletter for former FBI agents noted in March 1940 that "Tom McDade is doing a swell job with the law firm that represents Lloyds of London." Did You Know That, Grapevine, Mar. 1940, at 16.

59. Navy Wives to Join Husbands; Talbots Give Birthday Party, WAsH. Post, Apr. 7, 1946, at S2. This military society news article notes that " $[\mathrm{w}]$ hile the colonel was overseas, energetic Beatrice McDade donned a uniform herself and was an active member of the American Women's Voluntary Services[.]"

60. McDade, supra note 36 , at 19.

61. Introduction to Harvard and Homicide, in MAsterpIECES OF Murder 405 (Jonathan Goodman ed., 1992).

62. See Elago v. People, 84 Phil. Rep. 643 (S.C., Sept. 30, 1949). After Indalecio Elago's liquor business was closed by the government due to unsanitary conditions, he attempted to bribe a U.S. serviceman working with the Manila Police Department to have it reopened. The Army major was not persuaded by the offer of a diamond ring, and his 1945 deposition, along with that of supervising officer Col. McDade, sparked several evidentiary issues on appeal. Ultimately, the Philippine Supreme Court found that the Army officers' depositions had been properly taken but improperly admitted into evidence at trial, since both officers were still present in the country to testify if needed.

63. Liebson, supra note 35.

64. Thomas M. McDade, The Controller's Interest in the World Calendar, ConTroller, Aug. 1955, at 377 .

65. Navy Wives, supra note 59 , at $\mathrm{S} 2$. 
ter Innes Fergus McDade was born six months later. ${ }^{66} \mathrm{McD}$ ade was steadily promoted at General Foods, becoming the conglomerate's assistant controller in 1950; he was elected controller three years later. ${ }^{67}$

\16 This period of McDade’s life marked the beginning of both his publishing career and his personal collection of trial literature, which would intertwine for the Annals. ${ }^{68}$ In addition to writing the Dun's Review piece about his FBI training class that had caused such a stir within the Bureau, ${ }^{69} \mathrm{McD}$ ade submitted a story for the Fourth Annual Detective Short-Story Contest in Ellery Queen's Mystery Magazine, where he was one of 11 novice writers to place in the "new stories" category. ${ }^{70} \mathrm{His}$ first work of fiction appeared in the September 1949 issue. ${ }^{71}$ The editor's introduction noted that McDade's writing career began during his military service, "on the beach at New Guinea."72 McDade also began publishing in book collecting journals; the earliest such work was an enthusiastic recounting of early British trial broadsides from the author's personal collection, which reads a bit like a prototype for The Annals of Murder. ${ }^{73}$ McDade noted, "No collector should try to explain what prompts him to collect the things he does.... There is even less reason, in my own case, to account for a passion for collecting the literature of crime."74

I17 By 1956, the McDade family had relocated to a home in Purchase, New York. ${ }^{75}$ McDade's social orbit grew to include fellow book collectors, mystery writers, and true-crime aficionados. They formed a loose association called the Society of Connoisseurs in Murder, which had "no constitution, dues, or trappings of membership" save for a wallet card. ${ }^{76}$ The Society formed the framework for numerous dinner parties with like-minded crime enthusiasts. ${ }^{77} \mathrm{McD}$ ade served as

66. See AnCESTRY.COM, U.S., Social Security Death Index, 1935-2014, https://www.ancestry.com /search/collections/ssdi/ [https://perma.cc/TL8M-KLRA]. The McDades' daughter shared her name with a second child, who died in November 1944 at the age of one and is buried at Arlington National Cemetery. See Interment Control Forms, 1928-1962. Interment Control Forms, A1 2110-B. Records of the Office of the Quartermaster General, 1774-1985, Record Group 92. The National Archives at College Park, College Park, MD. The first Innes McDade's headstone at Arlington erroneously lists her as a "son" of the McDades. Telephone interview with Jared McDade (Nov. 8, 2017).

67. See General Foods Corp., Annual Report 17 (1954); McDade, Controller's Interest, supra note 64 , at 377 .

68. Smith, supra note 23, at 1616 . While employed by the FBI, McDade wrote of receiving bookseller catalogs that intrigued him, but he balked at the prices. His focus at that time was on books about Japanese art rather than true crime. McDade Journal, supra note 38, at Mar. 6, 1936.

69. McDade, supra note 53, at 19.

70. Ellery Queen, Introduction to The QueEN's AwARDs, 1949 vii, xi (Ellery Queen ed., 1949). Jared McDade remembers his father receiving his very first typewriter as part of a writing contest prize, most likely this one. Telephone interview with Jared McDade, supra note 66.

71. T.M. McDade, Let Me Help You with Your Murders, Ellery Queen's Mystery Mag., Sept. 1949, at 74. McDade's fellow FBI alumni teased him in their newsletter, although they seemed to have conflated the award-winning fiction piece with the Dun's Review article: "Tom McDade you better kick that dough you got from Ellory [sic] Queen into the Society Treasurer. We know you sold them a story on the Society." Keeping Up with Those You Know, Grapevine, Jan. 1949, at 2.

72. McDade, supra note 71, at 74 .

73. Thomas M. McDade, Gallows Literature of the Streets, in 3 New Colophon: A BooK-CollecTOR'S MiSCELLANY 120 (1950).

74. Id.

75. Thomas M. McDade, Lurid Literature of the Last Century: The Publications of E. E. Barclay, 80 Penn. Mag. Hist. \& Biog. 452, 464 (1956).

76. Smith, supra note 23 , at 1616-20.

77. Id. The Society of Connoisseurs in Murder was formal enough to be listed in directories of 
Society president and was also an active member of the Sherlock Holmes literary society, the Baker Street Irregulars. ${ }^{78}$ McDade's estate in Purchase became so well known by the tongue-in-cheek nickname "Scotland Yard" that "letters so addressed, without benefit of street name or number, would reach him."79

\section{The Annals of Murder}

I18 McDade's growing collection of American murder trial publications fueled his interest in compiling a bibliography of American murder trials to 1900, an ambitious project that took him years to complete.$^{80} \mathrm{~A}$ grant from the Ford Foundation enabled the work. ${ }^{81}$ It was not the first time that historians had tried to compile such information, as McDade well knew: "In the 1940s an attempt was made to provide a homicidal history of the country in a regional murder series. Nine volumes were issued, each reporting the famous cases of a separate city" 82

I19 McDade's publisher, University of Oklahoma Press, suggested that he follow the general style of its earlier bibliography on the Wild West..$^{83}$ The Annals of Murder is likewise organized alphabetically by perpetrator (and occasionally by victim, if the villain was unknown). Each listed pamphlet provides publication information, location codes for holding libraries, and a brief description. Many entries were drawn from McDade's personal collection of trial publications: "When he was compiling his remarkable bibliography, ... he scarcely needed to leave the library in the house he called Scotland Yard." ${ }^{44}$ Keeping the large number of items in order proved to be a challenge; Beatrice McDade complained of difficulties vacuuming

organizations, as one man discovered when researching a murder confession that he had found on an antique phonograph cylinder. McDade happily supplied him with details of the case and referred him to a fellow true-crime expert for more information. See Tim Brooks, The Last Words of Harry Hayward (A True Record Mystery), Antique Phonograph Monthly, June-July 1973, at 1 . Their annual dinner parties occasionally attracted the attention of local newspapers as well. See, e.g., Connoisseurs in Murder Convene, Citizen-Advertiser (Auburn, N.Y.), July 8, 1963, at 2; Richard G. Case, Killers "Lack Polish": Dinner Topic: Murder, A Fine Art, Syracuse Herald-Am., Apr. 16, 1967, at 21.

78. Introduction, supra note 61 , at 405.

79. Smith, supra note 23, at 1616. Indeed, in later professional correspondence, McDade described "Scotland Yard, Purchase, New York" as "my home address." Letter from Thomas M. McDade to Harold Weisberg (June 6, 1966) (on file with author). Son Jared recalls that there were no ZIP codes at that time, making this more casual approach to postal delivery perhaps less unusual than it would seem today. Telephone interview with Jared McDade, supra note 66.

80. Smith, supra note 23, at 1620.

81. Annals, supra note 14, at iv. This funding was likely through the Ford Foundation's University Presses program, which launched in 1956 and provided grants "to assist publication of works by scholars in the humanities and social sciences." Ford Found., The Ford Foundation Annual Report 28 (1961). The program was intended to facilitate the publication of scholarly works that required extensive research but likely lacked a major commercial audience. Id. at 36. University of Oklahoma Press received grant money through this program from fiscal years 1956-1962; although the University Presses funding program continued for several years after that, Oklahoma was no longer listed as a recipient school. Annual reports for the relevant period are available online from the Ford Foundation Library, https://www.fordfoundation.org/library/?filter=Annual\%20Report [https://perma.cc/JUZ6 -PVQM].

82. Thomas M. McDade, Book Review, 38 Minn. Hist. 234 (reviewing Walter N. Trenerry, Murder in Minnesota (1963)). He was referring to the Regional Murder Series, published by Duell, Sloan \& Pearce between 1944 and 1948. The nine cities covered are Boston, Charleston, Chicago, Cleveland, Denver, Detroit, Los Angeles, New York City, and San Francisco.

83. Smith, supra note 23, at 1620 (citing Six-Guns and SAdDle Leather: A Bibliography of Books and Pamphlets on Western Outlaws and Gunmen (Ramon Adams ed., 1951)).

84. Introduction, supra note 61 , at 405. 
the house, with Thomas's citation slips for each trial arranged on the floor. ${ }^{85}$ The Annals index includes the names of murderers and suspects, unfortunate victims, and locations (states, counties, and even ship names, for murders that occurred in U.S. waters). ${ }^{86}$

I20 Historical figures abound in the pages of the Annals. Two nineteenth-century U.S. presidents and the trials of their assassins combine for 55 of the Annals' 1126 entries: James A. Garfield edges out Abraham Lincoln by a single pamphlet. ${ }^{87}$ Less expected are the two sitting members of Congress who appear not as victims but as perpetrators: in 1856, Philemon T. Herbert, who represented California in the U.S. House, was acquitted for fatally shooting an unlucky waiter at a Washington, D.C., hotel. ${ }^{88}$ Three years later, a U.S. representative from New York was also acquitted after fatally shooting his wife's lover. ${ }^{89}$

I21 Other noteworthy names appear in McDade's commentary, although the indexing does not always reflect their presence. The senior Oliver Wendell Holmes testified as a witness in the infamous trial of Dr. George Parkman's killer, Harvard professor John White Webster; Holmes's office at Harvard was directly above the murder site. ${ }^{90}$ In 2016, the New Yorker's Page-Turner blog summarized many other notable appearances in the Annals:

Hugh Stone was urged to repent by none other than Cotton Mather, whose execution sermon was printed with the murderer's own gallows speech in 1690. The debtor Josiah Burnham was defended, unsuccessfully, by Daniel Webster. The jury that acquitted Thomas O. Selfridge included Paul Revere. The defense team for Levi Weeks was made up of the current Broadway duo of Alexander Hamilton and Aaron Burr. John C. Colt, who murdered a man named Samuel Adams in 1841, became the subject of a pamphlet because he used a hatchet and not a pistol in the crime-notable because his brother was Samuel Colt, who didn't miss the opportunity to demonstrate one of his patented revolvers at the trial. ${ }^{91}$

I22 Still more historical figures lurk beneath the surface of cases in the Annals, ready to be revealed to curious researchers. In the trial of Matthias the Prophet, a bizarre religious leader accused and acquitted of poisoning one of his followers in 1835, the Annals omits the cloud of suspicion hanging over the victim's servant, a freed slave named Isabella van Wagenen. Never charged, Isabella would ultimately win a libel suit against the prophet's wife. Isabella later changed her name to the one for which she is better known: Sojourner Truth. ${ }^{92}$

85. Smith, supra note 23 , at 1620.

86. AnNALs, supra note 14 , at 334-60.

87. See AnNALs, supra note 14, at 119-25 (listing trial accounts of Garfield assassin Charles Julius Guiteau); id. at 180-85 (coverage of Lincoln's assassination). William McKinley's September 1901 assassination came one year too late for the Annals' 1900 cut-off date. See LeRoy Parker, The Trial of the Anarchist Murderer Czolgosz, 11 YALE L.J. 80 (1901).

88. AnNALs, supra note 14, at 139 (Philemon T. Herbert).

89. Id. at 258 (Daniel E. Sickles). The victim was Philip Barton Key II, son of "The Star-Spangled Banner" author Francis Scott Key.

90. Id. at 311 (John White Webster). The senior Dr. Holmes also unwittingly purchased the corpse of another Annals victim, whose murderer brought her body to Boston Medical College. Id. at 197 (John McNab).

91. Cep, supra note 17. Daniel Webster also defended Michael Powers, equally unsuccessfully. AnNALS, supra note 14, at 230. He made another appearance in the trial of John Francis Knapp, this time as prosecutor. $I d$. at 167-68.

92. See Thomas M. McDade, Matthias, Prophet Without Honor, 62 N.Y. Hist. Soc'y Q. 311, 333-34 (1978). 
I23 The Annals also features its share of lesser-known cases, unknown victims, and commonplace motives: spurned lovers, business grudges, and schemes for family inheritances. Some, like the 1871 circus-tent shooting described in The Ames Tragedy, have been all but forgotten. ${ }^{93}$ Murders are committed by spouses, soldiers, sailors, and saloonkeepers, among other professions. Weapons vary widely, although poison features heavily; McDade notes in his introduction that arsenic was once readily available over the counter as a popular rat poison. ${ }^{94}$ Axes and guns were equally common sights in the Annals. ${ }^{95}$ Some unfortunate victims were dispatched with pitchforks, ${ }^{96}$ cricket bats, ${ }^{97}$ and pike poles; ${ }^{98}$ another was strangled with a piece of twine. ${ }^{99}$

I24 "Not every collector is cognizant of the value of the material to a social historian," McDade wrote in 1973, "but in the fullness of time it all assumes its place and value in the source material for a period." 100 The Annals is filled with information about American criminal law milestones and first-of-their-kind cases. McDade's introduction notes that the first murder in the American colonies was a 1630 shooting. ${ }^{101}$ William Arrison holds the distinction of "the first bomb case in America," in 1854. ${ }^{102}$ The year 1881 marked the first time a white man was tried for murder of a Chinese immigrant. ${ }^{103}$ The 1890 s marked the emergence of "our greatest mass murderer" and an early example of what would later be known as a serial killer: Herman W. Mudgett, better known as H. H. Holmes. ${ }^{104}$

I25 The Annals also tells an historical story of American legal publishing: namely, how the rising 19th-century newspaper industry largely eliminated the pamphleteering business. Particularly notorious early trials commonly have multiple narratives in the Annals (one 1832 case was featured in more than 20 publications); just a few decades later, however, trials as infamous as Lizzie Borden's merited only a handful of entries in McDade's work, as newspapers became the go-to source for legal reporting. ${ }^{105}$ This decline in individual trial broadsides and pam-

93. Annals, supra note 14, at 164 (John R. Kelly). The defendant was tried after he fired shots into a circus tent, killing two men "and wounding the mother of the albino twins in the side show." The case was featured in volume 4 of the American State Trials series, but otherwise garnered little attention.

94. Id. at xix.

95. Id. at $\mathrm{xx}$.

96. Id. at 253 (David Sanford).

97. Id. at 224 (Thomas W. Piper).

98. Id. at 228 (Andrew P. Potter). The dispute was over a borrowed watch.

99. Id. at 71 (Charles Cunningham). The defendant felt he had been cheated by the victim in a game of hustlecap, a coin-toss game of the era. See Hustle-cap, VII Oxford English Dictionary 517 (2d ed. 1989).

100. Thomas M. McDade, Introduction to the Reprint Edition, in Charles Sutton, The New York Tombs: Its Secrets and Its Mrsteries: Life and Death in New York's Famous Prison v, xii (James B. Mix \& Samuel A. MacKeever eds., 1973).

101. AnNALs, supra note 14, at xix. There is no corresponding Annals entry for the trial of John Billington; as McDade notes, "before 1800 reports of trials in separate publications were rare." Id. at v. McDade did write a book chapter detailing this early American murder, trial, and execution. Thomas M. McDade, The Pioneer Effort of John Billington, in The Quality of Murder; Three Hundred Years of True Crime 15 (Anthony Boucher ed., 1962).

102. AnNALs, supra note 14, at 12 (William Arrison).

103. Id. at 67 (John J. Corcoran). The defendant was acquitted of the stabbing of Lee Teep.

104. Id. at 210 (Herman W. Mudgett). H.H. Holmes was the subject of Erik Larson's 2003 bestseller Devil in the White City: Murder, Madness, and Magic at the Fair that Changed America.

105. Smith, supra note 23 , at 1622. 
phlets can be tracked alongside the rise of wire services in the United States; by the 1890s, advancements in wireless transmission, development of small-market newspapers, and increasing rates of public literacy all contributed to this cultural shift in murder trial reporting. ${ }^{106}$

\section{After the Annals}

I26 The Annals of Murder earned a warm reception by critics, in both popular and academic circles. The New York Times described it as of "great value to collectors" as well as "to the less bibliophilous enthusiast of murder. . . . [A] delight to read." 107 Newsweek hailed the arrival of "a scholarly volume . . . which should lift the hearts of devoted students of the theory and practice of homicide." 108 A legal history journal praised McDade's introduction as "filled with useful, professional, and memorable information about arsenic, drunkenness, insanity, and the legal rights of murderers as interpreted by our fathers," 109 while a new acquisition writeup by the Rutgers University Library noted, "There are few bibliographies more intriguing. ... Annals of Murder has been put together with a good deal of zest."110 In April 1962, the Annals received a special Edgar Allan Poe Award from the Mystery Writers of America. ${ }^{111}$

I27 Among book collectors, "Not in McDade" became a common sight in advertisements for antique trial pamphlets. ${ }^{112}$ It seems likely that many of the items so advertised failed to meet McDade's criteria for inclusion: the Annals deliberately omits manslaughter trials, execution sermons lacking sufficient facts of the case, and fictional accounts that were presented as true occurrences. ${ }^{113}$ Considering these selection criteria, errors of omission in the Annals are less common, although not unprecedented. In the homicide trials chapter of his seminal 1998 Bibliography of Early American Law, the late Yale Law School professor and library director Morris L. Cohen cited about 70 titles from the Annals era as "Not in McDade," with only a half-dozen noted as variant editions or printings of McDade's featured trials. ${ }^{114}$ Still, when considering the scope of his bibliography and the inherent diffi-

106. See Bill James \& Rachel McCarthy James, The Man from the Train: The Solving of a Century-Old Serial Killer Mystery 203-04 (2017).

107. Anthony Boucher, A Report on Criminals at Large, N.Y. Times Book Review, Dec. 24, 1961 , at 12 .

108. Write Me a Murder-And the Authors Oblige, Newsweek, Jan. 1, 1962, at 54.

109. Lewis Leary, Review, The Annals of Murder: A Bibliography of Books and Pamphlets on American Murder from Colonial Times to 1900 by Thomas M. McDade, 86 Penn. MAg. Hist. \& Biog. 213-14 (1962).

110. Donald A. Sinclair, Gifts and Acquisitions, 25 J. Rutgers U. LiBr., June 1962, at 28, 31.

111. "Gideon's Fire" Wins Poe Prize for Novel, N.Y. Times, Apr. 14, 1962, at 23.

112. Smith, supra note 23, at 1620. Son Jared recalls the story of a book dealer who unknowingly informed Thomas McDade himself whether a particular item for sale was listed in McDade. His father growled in response, "I'm McDade." Telephone interview with Jared McDade, supra note 66.

113. AnNals, supra note 14 , at v-vi.

114. See 4 Morris L. Cohen, Bibliography of Early American Law 389-690 (1998). Several notable McDade omissions can also be discovered in Jay Robert Nash's 1980 book Murder, America, which features write-ups of notorious American murder cases from 1773-1977. Of the 25 included cases dated before the Annals' 1900 cut-off, 15 trials received coverage in the Annals. Two of the omitted 10 appear to fall outside of McDade's geographic scope, with one a serial killer who 
culties of the research involved at the time, McDade's comprehensiveness remains remarkable.

I28 For researchers, the Annals became a reliable resource for historical murder trials. Its coverage of early trial publications supported the scholarship of later books, articles, and dissertations. ${ }^{115}$ The Annals also provided seed data for the Espy File database, a collection of information on American executions. ${ }^{116}$ Yet, despite its positive critical reception and enduring use in scholarship, The Annals of Murder disappeared from Books in Print in the late 1970s, after University of Oklahoma Press provided its remaining stock to the New Jersey bookseller Patterson Smith. ${ }^{117}$ Collectors have lamented the obscurity of McDade's bibliography ("out of print for far too long," groused one author as early as 1992). ${ }^{118}$ McDade himself could have predicted this fate, noting in 1964 that "[c] ompared with the hundreds of detective novels which are published each year, there are not more than a score of true crime books and rare is the one that reaches a second printing." 119

I29 The Annals appeared in an equally troubled market for American trial publishing, at least compared to the long-running Notable British Trials series in the United Kingdom. "For the American crime buff who may ask why there is not an American Notable Trials Series," McDade wrote in 1964, "the answer is that there have been many attempts to publish such a series here. In fact, in the past one hundred and eighty years no less than seven new publishing ventures have endeavored" to report the proceedings of noteworthy American criminal trials. ${ }^{120}$ These included the University of Missouri Law School's American State Trials series, ${ }^{121}$ published from 1914 to 1936 and largely reliant on material from historical pam-

operated primarily in Canada and Europe (although his earliest victims were American) and the other a murder that took place aboard a ship bound for Argentina. The remaining 8 omissions from McDade do contain some surprising oversights, including the first woman to be executed in Minnesota (Ann Bilansky). See Jay Robert Nash, Murder, America: Homicide in the United States from the Revolution to the Present 62-66 (1980).

115. See, e.g., Sara L. Crosby, Poisonous Muse: The Female Poisoner and the Framing of Popular Authorship in JaCKSONIAN AMERICA 14-15 (2016) (building a dataset on poisoning murders from Annals entries); Negley K. Teeters, “. . Hang by the Neck . . ”. The Legal Use of Scaffold and Noose, Gibbet, Stake and Firing Squad from Colonial Times to the Present ix (1967) (noting debt of gratitude to McDade and his publisher for allowing use of Annals content); Daniel A. Cohen, Homicidal Compulsion and the Conditions of Freedom: The Social and Psychological Origins of Familicide in America's Early Republic, 28 J. Soc. Hist. 725, 725 (1995) (expanding upon McDade's “admirably thorough" findings of familicide); Sean Timothy Moore, Violence, Gender, and the Law in New York State, 1790-1860, at 253 (2003) (unpublished Ph.D. dissertation, University of Connecticut) (using the Annals to enhance creation of database on New York murder and manslaughter cases).

116. Smith, supra note 23, at 1620. The Espy File, now updated to 2002, can be found at https://deathpenaltyinfo.org/executions-us-1608-2002-espy-file [https://perma.cc/3HFW-2GY3].

117. See, e.g., 1 Books IN PRINT 1972, at 1632 (1972) (listing both University of Oklahoma Press and Smith as suppliers of the Annals). The title's final listing in Books in Print (by that point exclusively supplied by Patterson Smith) was the 1978 edition. See 2 Books IN PrINT 1978-1979, at 2252 (1978).

118. Introduction, supra note 61 , at 405.

119. Thomas M. McDade, The "Corpse" in the Library: A Brief Note on American Trial Publishing, 15 Ам. Воок Collector, Sept. 1964, at 8.

120. Id.

121. American State Trials: A Collection of the Important and Interesting Criminal Trials which have Taken Place in the United States from the Beginning of our Government to the Present Day: with Notes and Annotations (John D. Lawson ed., 1914). 
phlets. ${ }^{122}$ Subsequent attempts by different publishers to develop a notable American trials series, including one created at the suggestion of satirist H.L. Mencken, all withered away after the initial few volumes due to poor sales. ${ }^{123}$

I30 Perhaps because of this unprofitability of true-crime trial monographs, Thomas M. McDade never released another book. One idea for a book about poisonous mushrooms never advanced beyond the preliminary research stage. ${ }^{124}$ McDade did extensively research and write an unpublished manuscript about the 1916 Preparedness Day Bombing in San Francisco, which killed 10 and wounded dozens more; a subsequent trial resulted in the wrongful conviction of two labor leaders, Thomas Mooney and Warren K. Billings. ${ }^{125}$ McDade would later describe the Mooney-Billings affair as an example of notorious "cases which have tortured the conscience of the American public." ${ }^{26}$ He drafted-fully in some cases, partially in others - 10 chapters of the planned book before abandoning the manuscript, which now resides along with his interview notes and press clippings at the Labor Archives and Research Center at San Francisco State University. ${ }^{127}$

\section{Conclusion}

I31 Thomas M. McDade retired from the General Foods Corporation by 1972. ${ }^{128}$ He remained active in his retirement, publishing regularly throughout the 1970 s and 1980s in various magazines and anthologies. ${ }^{129}$ McDade also volunteered his legal and accounting services to the poor. ${ }^{130} \mathrm{McDade}$ visited the county jail in Valhalla, New York, each week to provide legal services to prisoners; ${ }^{131}$ he also served as "legal counselor" to another prison. ${ }^{132}$ In a parolee rights case before New York's highest court in 1973, McDade authored an amicus curiae brief for the Legal Aid Society of Westchester County. ${ }^{133}$

I32 Thomas McDade’s writing credits dry up by the early 1990s, and his original writings even sooner; his final few publication credits were reprints of prior writings. In the 1990s, an ailing McDade moved to a nursing home in Southbury,

122. McDade, supra note 119 , at 11 .

123. Id. at 11-12.

124. Telephone interview with Jared McDade, supra note 66.

125. See Richard H. Frost, The Mooney Case (1968).

126. Thomas M. McDade, Book Review, 55 N.Y. Hist. Soc'y. Q. 99, 100 (1971) (reviewing Andy Logan, Against the Evidence: The Becker-Rosenthal Affair (1970)).

127. See Online Archive of California, Finding Aid to the Tom Mooney and Warren K. Billings Collection (2017), http://pdf.oac.cdlib.org/pdf/sfsu/larc/mooneybillings.pdf [https://perma .cc/GCW7-Y7YH]. It seems likely that McDade felt preempted by Curt Gentry's extensive chronicle Frame-Up: The Incredible Case of Tom Mooney and Warren Billings (1967), published by Norton to much fanfare. See David Cort, Trial and Error, N.Y. Times, June 18, 1967, at 246.

128. Liebson, supra note 35. McDade's final title at the company was Director of Security and Auditing. Telephone interview with Jared McDade, supra note 66. General Foods elected a new controller in 1965. General Foods Corp., AnNuAl RePort 1966, at 9 (1966).

129. See infra Appendix, pp. 296-306.

130. Introduction, supra note 61, at 405.

131. McDade's wife Beatrice also taught handicraft classes at the same institution, where the inmates referred to the couple as "Pa" and "Ma." Smith, supra note 23, at 1623.

132. Thomas M. McDade, Prisons: Getting In-Getting Out, in Murder Ink: The Mystery Reader's Companion 393 (Dilys Win ed., 1977).

133. People ex rel. Calloway v. Skinner, 33 N.Y.2d 23, 29 (1973). 
Connecticut; ${ }^{134}$ he died there on March 2, 1996. ${ }^{135}$ More than 150 friends and wellwishers attended his memorial service in Massachusetts, where the McDades owned a second property. ${ }^{136}$ His widow, Beatrice, passed away in Southbury eight years later. ${ }^{137}$ The McDades' third child, actress and playwright Innes Fergus McDade, died in Massachusetts in 2010. ${ }^{138}$ The "Scotland Yard" estate in Purchase, New York, is now owned by surviving son Jared; it has remained in the McDade family since $1956{ }^{139}$

I33 "Several inches more than six feet tall, he is also a big man in unvisible respects," is how one friend and collaborator described Thomas M. McDade. ${ }^{140}$ McDade's body of work is similarly large yet obscure-one seminal reference bibliography, now out of print for close to four decades; and dozens of engaging, enlightening short pieces buried in poorly indexed historical journals, most of which have not yet been digitized. The appendix to this article represents the first known effort to compile a list of Thomas M. McDade's extensive writings in one place. In the spirit of The Annals of Murder, each entry includes a brief description, albeit with only a pale imitation of his singular humor.

134. Telephone interview with Jared McDade, supra note 66.

135. Smith, supra note 23 , at 1613.

136. Telephone interview with Jared McDade, supra note 66.

137. Connecticut Dep't of Health, Connecticut Death Index, 1949-2012, searchable at ANCESTRY.COM, https://www.ancestry.com/search/collections/Ct1949-96 [https://perma.cc/4PUP-L3MN].

138. See Innes Fergus McDade, http://www.legacy.com/obituaries/bostonglobe/obituary.aspx?n =innes-fergus-mcdade\&pid=141190744 (last visited June 1, 2019).

139. Telephone interview with Jared McDade, supra note 66.

140. Introduction, supra note 61, at 405. 


\section{Appendix: Thomas M. McDade: An Annotated Bibliography}

I34 Thomas M. McDade was a more prolific writer than his single published book credit would suggest, and his writing appeared in many relatively obscure sources. I reviewed numerous online and historical print indexes to gather these materials, but it is entirely possible that some of McDade's publications remain buried. Because McDade published under five variations of his name, the author name styling is included in each entry.

McDade, Thomas. "Bad Little Johnny." Brooklyn Daily Eagle, October 12, 1919, JE7. Credited to "Thomas McDade (Age 11)," this short poem was featured alongside other youth contributions in a special "Junior Edition" section of McDade's local daily newspaper. Although the meter needed work, the young poet crafted an effective picture of neighborhood troublemaker Johnny, who was fond of vandalism, stealing pears from his mother's pantry, and picking fights with other boys.

McDade, Thomas E. "An Application of the Law of Contracts for Personal Services." St. John's Law Review 4, no. 1 (1929): 112-14.

Examines the strange case of Brearton v. DeWitt, in which Mae Brearton gave up her place in society to undergo experimental medical treatment by Elden DeWitt; in exchange, DeWitt would pay Brearton $\$ 1000$ a month for life. When DeWitt died, Brearton attempted to collect the payments from his estate; in 1929, the New York Appellate Division found that their contract was for personal services and thus did not survive DeWitt's death. ${ }^{141}$ Law student McDade agreed with the majority's position, although the New York Court of Appeals reversed the lower court one year later. ${ }^{142}$

McDade, Thomas E. "Rights and Obligations of Assignees of Contracts for the Sale of Real Property." St. John's Law Review 4, no. 2 (1930): 266-71.

Explores New York case law on contracts for real property, including the best methods for determining the parties' intent concerning assignability.

McDade, Thomas M. “Accountant's Liability to Third Persons." St. John's Law Review 5, no. 1 (1930): 76-81.

A subject undoubtedly dear to McDade's heart given his background in accounting, this piece explores several New York court opinions on the matter of duties owed by accountants to nonclients who may reasonably rely on an accountant's certified statement.

McDade, Thomas M. “Best Evidence Rule: Oral Proof of Contents of Writings.” St. John's Law Review 5, no. 2 (1931): 229-33.

Overview of New York evidence law that the best evidence of a written document is the document itself, rather than oral testimony. McDade would later be at the center of such a dispute during his Army service in the Philippines. ${ }^{143}$

McDade, Thomas M. "Presumption of Suicide, Presumption of Innocence." St. John's Law Review 6, no. 1 (1931): 127-30.

Examines People v. Miller and People v. Creasy, two New York Court of Appeals decisions that discuss whether the presumption of a criminal defendant's innocence requires a jury instruction to presume that the victim committed suicide. McDade would later revisit the Creasy case in a 1985 publication. 
McDade, Thomas M. Review of American Family Law: Volume II - Divorce and Separation, by Chester G. Vernier. St. John's Law Review 7, no. 1 (1932): 170-71. A generally positive review of the family law volume in Vernier's treatise series. McDade praised the 50-state statutory survey tables but expressed skepticism that the volume would aid "a deeper comprehension of our family problems" (p.171).

McDade, Thomas M. “The Most Carefully Selected Men in the World." Dun's Review, May 1949, 19-21+.

This overview of the FBI selection and training process sparked a few internal FBI memos. ${ }^{144} \mathrm{McDade}$ describes candidate interviews and background checks, with a few anonymized anecdotes of successes and failures. In a nod to the publication's business audience, McDade concludes by discussing the varied careers and industries of members of the Society of Former Special Agents of the FBI.

McDade, T.M. "Let Me Help You with Your Murders.” Ellery Queen's Mystery Magazine 13, no. 9 (September 1949): 74-80.

Noted as one of 11 "first stories" to receive a special prize in the magazine's annual short story contest, this is one of only a handful of fiction works published by McDade. Praised in the editor's introduction for "ingenious gimmicks" and combination of "wickedness with whimsy" (p.74), the story follows two detectives who investigate a strange classified ad and discover an unexpected link to an open homicide case.

McDade, Thomas M. "Gallows Literature of the Streets." New Colophon: A BookCollector's Miscellany 3 (1950): 120-27.

McDade's first piece about his personal collection of trial literature focused on early British broadsides. Contains some interesting musings about the appeal of these publications to the British working classes, as well as the appeal of collecting them in the modern age.

McDade, Tom. "McDade Tells About '34 Training Class." Grapevine, June-July $1954,16-19+$.

In a 20 -year reunion of sorts, McDade tracks down the 29 graduates of his 1934 FBI training class and reports on the whereabouts of each. Ten were still with the Bureau; others worked primarily in law practice, others government service or academia.

McDade, Thomas M. “The Controller's Interest in the World Calendar." Controller, August 1955, 377-79+.

McDade details the advantages of a proposed perpetual World Calendar, which gained some traction in both the international law and accounting communities during the 1950s. The World Calendar would have equalized quarters into 91 days, fixed all holidays onto a particular day of the week, and added calendarstabilizing "Worldsday" holidays on December 31 (and June 31 in leap years).

McDade, Thomas M. “The Controller's Interest in the World Calendar.” Journal of Calendar Reform 25 (1955): 125-31.

A reprint of the previous piece in the journal of the World Calendar Association, featuring a new author photo and biographical introduction.

McDade, Thomas M. "Lurid Literature of the Last Century: The Publications of E.E. Barclay." Pennsylvania Magazine of History and Biography 80, no. 4 (1956): 452-64.

A brief history of 19th-century American publisher Erastus Elmer Barclay, an 
impresario of sensational, fictionalized trial account pamphlets. McDade summarizes several of the lurid accounts and describes Barclay's business practices over five decades of publishing.

McDade, Thomas M. "Sherlock Holmes and the F.B.I." Ellery Queen's Mystery Magazine 29, no. 2 (February 1957): 96-103.

$\mathrm{McDade}$ compares methods of investigation between the era of Sherlock Holmes and the modern FBI, including use of informants, firearms, fingerprint and handwriting analysis, and interrogation techniques.

McDade, Thomas M. "Lurid Literature of the Last Century: The Publications of

E.E. Barclay." American Book Collector 8, no. 1 (September 1957): 15-25.

Reprint of the E.E. Barclay piece from Pennsylvania Magazine of History and Biography, with no apparent additions or changes.

McDade, Thomas M. "Experience under the 1954 Act and Management Responsibility for Depreciation Policy." In Depreciation and Taxes, edited by E. Cary Brown et al., 1:29-38. Princeton, NJ: Tax Institute, 1959.

Still a controller at General Foods during this period, McDade contributed this conference paper to a November 1958 Tax Institute symposium, published as a book in 1959. It examines the legislative history and effects of the 1954 Internal Revenue Code changes on depreciation practices.

McDade, Thomas M. “The Parkman Case: A Book Collector’s Footnote to 'America’s Classic Murder.” American Book Collector 9, no. 9 (May 1959): 9-14.

Lengthy write-up of the notorious 1849 murder of Dr. George Parkman by Harvard professor John W. Webster, who killed and dismembered Parkman when he came to the laboratory to collect on a debt. Parkman's corpse was eventually discovered by a suspicious Harvard Medical College janitor. The trial and 1850 execution would be featured in 18 different pamphlets in the Annals; a similar checklist of trial publications is included here.

McDade, Thomas M. “The Month at Goodspeed's.” American Book Collector 11, no. 8 (September 1960): 8-10.

An appreciation of the bookseller catalogs from Boston's venerable Goodspeed's Book Shop. From the 1920s to the 1960s, catalog editor Norman L. Dodge included scholarly writing about antique books in the sales catalog.

McDade, Thomas M. The Annals of Murder: A Bibliography of Books and Pamphlets on American Murders from Colonial Times to 1900. Norman: University of Oklahoma Press, 1961.

Not much more to be said here; see pp. 289-92 for a detailed treatment.

McDade, Thomas M. "Heads and Holmes." Baker Street Journal 11, no. 3 (September 1961): 162-66.

Phrenology meets literature's greatest detective in this fanciful piece, where McDade describes the 19th-century medical fad and dissects a hypothetical phrenological chart of Holmes's head.

McDade, Thomas M. “The Pioneer Effort of John Billington.” In The Quality of Murder: Three Hundred Years of True Crime, edited by Anthony Boucher, 15-18. New York: E.P. Dutton, 1962.

This piece appeared in a compilation of true-crime stories by members of the Mystery Writers of America, edited by the man who had reviewed Annals favorably in the New York Times. McDade describes the hanging of John Billington, a Mayflower passenger who shot fellow settler John Newcomen in 1630. (An indi- 
vidual account of Billington is not featured in the Annals, though the introduction references this murder as the earliest known example in America.)

McDade, Thomas M. Review of Murder in Minnesota, by Walter N. Trenerry. Minnesota History 38, no. 5 (1963): 234.

McDade was suitably impressed by his fellow "murder fancier" for including 14 of 16 cases that were unknown to his reviewer.

McDade, Thomas M. “The 'Corpse' in the Library: A Brief Note on American Trial Publishing." American Book Collector 15, no. 1 (September 1964): 8-12.

Outlines three centuries of attempts to publish continuing series of notable American criminal trials, with particular attention to the travails of 20th-century efforts.

McDade, Thomas M. “The First Conanical Toast.” Baker Street Journal 16, no. 1 (March 1966): 23.

A celebratory poem for Pola Stout, which McDade delivered at a dinner of the Baker Street Irregulars on January 7, 1966. Pola Stout was a well-known textile designer who married the mystery writer Rex Stout; ${ }^{145} \mathrm{McD}$ ade's poem was likely written in honor of their wedding.

McDade, Thomas M. “A Day at the Sale." Baker Street Journal 16, no. 4 (December 1966): 202-04.

McDade's recollection of a March 1966 Conan Doyle manuscript auction, which he attended although he could not afford to participate. He recorded the items on offer and the sale prices to the best of his memory, noting, "I can't say who did buy them, but they paid plenty" (p.202).

McDade, Thomas M. “The Mooney-Billings Case." Unpublished book manuscript, ca. $1965-1967$.

McDade extensively researched an unpublished second book on the 1916 Preparedness Day parade bombing in San Francisco, which killed 10 and injured dozens more. The murder convictions of two labor organizers were later found to be based on perjured testimony, and the case became a famous example of wrongful convictions in America. McDade drafted 10 of a planned 16 chapters, which were in varying stages of completion when he abandoned the project. He donated his manuscript and research notes to San Francisco State University's Labor Archives and Research Center.

McDade, Thomas M. Foreword to “. . . Hang by the Neck . . .”: The Legal Use of Scaffold and Noose, Gibbet, Stake and Firing Squad from Colonial Times to the Present, by Negley K. Teeters, v-vii. Springfield, IL: Charles C. Thomas, 1967.

In the brief introduction to a book drawn largely from the contents of the Annals, McDade muses on the study of history through social customs of a particular time period, such as execution practices.

McDade, Thomas M. Review of Crime and Punishment in Early Massachusetts, 1620-1692: A Documentary History, by Edwin Powers. New York Historical Society Quarterly 51, no. 3 (1967): 294-96.

McDade recommended this historical treatment of Massachusetts criminal law and practice, expressing admiration for the author's research into archival sources. 
McDade, Thomas M. "Christian Brown-Wanted for Murder.” New York Historical Society Quarterly 52, no. 2 (1968): 119-38.

The story of 19th-century true-crime publisher Christian Brown, with lengthy detours into the facts behind some of his most sensational publications.

McDade, Thomas M. “The Assassination Industry: A Tentative Checklist of Publications on the Murder of President John F. Kennedy." American Book Collector 18, no. 10 (Summer 1968): 8-14.

An attempt to compile the many publications related to the Kennedy assassination, exempting newspapers and periodicals with the exception of special issues.

McDade, Thomas M. "Baker Street and Canon Lore." American Book Collector 19, no. 1 (September 1968): 17-18.

A review of William S. Baring-Gould's Annotated Sherlock Holmes, a two-volume set of Doyle's novels and short stories featuring the master detective, which are known to Holmes devotees as "the Canon" (p.17). Arranged not in the order of publication but chronologically by the events of the tales, this presentation was, McDade noted, not for the casual Sherlockian.

McDade, Thomas M. Review of The Pinkertons: The Detective Dynasty that Made History, by James D. Horan. Pennsylvania Magazine of History and Biography 93, no. 2 (1969): 292.

The reviewed book revisited the well-worn history of the Pinkerton private detective agency. Although McDade was unimpressed by numerous factual and typographical errors, he found it a worthy text for its inclusion of archival material from the Pinkerton family.

McDade, Thomas M. Review of The Trial of the Assassin Guiteau: Psychiatry and the Law in the Gilded Age, by Charles E. Rosenberg. New York Historical Society Quarterly 53, no. 3 (1969): 298-99.

Reviews a study of President James Garfield's assassin, whose trial raised questions about the insanity defense. Although the claim proved unsuccessful at trial, McDade noted that only a few years after Guiteau's execution, the medical community was "almost unanimous" (p.298) that he had indeed been insane.

McDade, Thomas M. "Death in the Afternoon." Westchester Historian 46, no. 1 (Winter 1970): 1-7.

Vivid description of the 1842 death of Tom McCoy from injuries sustained during a 120-round boxing match in Hastings, New York. McCoy's death sparked national outrage about the scourge of prizefighting, and the match's opponent, promoter, and other organizers were indicted for manslaughter. McDade reports the fate of all defendants.

McDade, Thomas M. Review of Against the Evidence: The Becker-Rosenthal Affair, by Andy Logan. New York Historical Society Quarterly 55, no. 1 (1971): 99-100.

The reviewed book was an investigation into the trial and execution of a New York City police lieutenant accused of procuring the 1912 murder of a local bookmaker. McDade found the research impressively thorough and the writing to be entertaining, but thought the author could have taken a stronger stance on the moral questions of the defendant's innocence.

McDade, Thomas M. "Edward Gorey: An American Gothic." American Book Collector 21, no. 7 (May 1971): 12-17.

It makes sense that the compiler of the Annals would appreciate the macabre humor of artist Edward Gorey. This piece includes a bibliography of Gorey's 
illustrations in books and articles, prefaced with a thoughtful biographical essay by McDade. At the time, McDade noted that very little had been published in the popular press about Gorey's work; one year later, his early works would be compiled into the breakthrough volume Amphigorey (1972).

McDade, T.M. Review of A Catalogue of Crime: Being a Reader's Guide to the Literature of Mystery, Detection, and Related Genres, edited by Jacques Barzun and Wendell Hertig Taylor. American Book Collector 22, no. 1 (September 1971): 3-4.

This review of an ambitious bibliography took the editors to task for attempting to cover both fiction and nonfiction in one overstuffed volume, whose organization McDade found haphazard. He was particularly unimpressed with the true-crime section, calling it a "disaster" (p.3), but did note that the coverage of detective fiction was a suitable complement to other existing reference guides for mystery fiction.

McDade, Thomas M. Introduction to the Reprint Edition of The New York Tombs: Its Secrets and Its Mysteries: Life and Death in New York's Famous Prison, by Charles Sutton, edited by James B. Mix and Samuel A. MacKeever, v-xiii. Montclair, NJ: Patterson Smith, 1973.

In a new introduction to the 1874 classic by the warden of New York County Jail, McDade reflects on the professed morality of lurid 19th-century crime writings, and recounts the history of the tombs and its most famous inhabitants, including a few (Edward Stokes, Emma Burdell) who also populated the Annals.

McDade, Thomas M. Review of The Mystery and Detection Annual, edited by Donald Adams. American Book Collector 24, no. 1 (September-October 1973): 2.

McDade noted the potential merits of a new annual volume on detective fiction but panned its tangential article selections and outdated book reviews. He expressed hope for improvement in the second volume-which would ultimately prove to be its last.

McDade, Thomas M. "After the Fact or the Murderous Career of Louis Clark Jones." New York Folklore 1, no. 1 (Summer 1975): 15-19.

An appreciation of former New York Historical Association president Lou Jones, who was a member of McDade's collective the Society of Connoisseurs in Murder. Jones organized the group's 1959 meeting in Cooperstown, which later inspired Jones to write a 1966 article about a notorious local murderer.

McDade, Thomas M. "Prisons: Getting In-Getting Out." In Murder Ink: The Mystery Reader's Companion, edited by Dilys Win, 390-95. New York: Workman, 1977.

Practical advice to writers of mystery and detective stories, framed as McDade's recollections of visiting inmates in various prisons. Judging by the inclusive pages for McDade's name in the index, he also likely penned the unsigned "Interview with a Warden" (p.394), which immediately follows his signed piece. He may have also contributed the uncredited subsequent two-page spread of photographs entitled "Accommodations at Sing Sing" (pp.396-97).

McDade, Thomas M. “The Nut Letter Desk.” In I, Witness: Personal Encounters with Crime by Members of the Mystery Writers of America, edited by Brian Garfield, 301-12. New York: Times Books, 1978.

Despite the less-than-politically-correct title (taken from the FBI's derogatory nickname for its "Miscellaneous Desk") and references to "girl receptionists" 
(p.310), this is an equal-parts sympathetic and cynical reflection on how FBI Agent McDade handled letters and visits from citizens afflicted with mental illness.

McDade, Thomas M. "Matthias, Prophet Without Honor." New York Historical Society Quarterly 62, no. 4 (1978): 311-34.

Among McDade's most detailed articles is this story of Matthias the Prophet (a.k.a. Robert Matthews), an austerity-preaching, wife-swapping religious leader who was acquitted of murder in the death of follower Elijah Pierson. This is a lengthy account of the religious group's practices and the subsequent murder trial. Abolitionist Sojourner Truth makes a surprise appearance at the end of this tale.

McDade, T.M. “Delayed Encounter." In Mystery Writers Annual 1979, edited by the Mystery Writers of America, 6-7. New York: Mystery Writers of America, 1979.

First-person account of correspondence and an eventual meeting with former Barker gang associate Alvin "Creepy" Karpis in Spain, following Karpis's 26-year sentence in Alcatraz. The pair traded stories about "the bad-good old days" (p.6).

McDade, Thomas M. "Karpis Recalls His Crime Spree of 1930s in Talks with McDade." Grapevine, May 1980, 36-38.

A reprint of "Delayed Encounter" in the newsletter of the Society of Former Special Agents of the FBI. Identical, save for a typo correction from the original and a variant photograph of the pair.

McDade, T.M. “Crime Hunt: The Wallace Case." Armchair Detective 14, no. 4 (Fall 1981): 374-75.

This piece, on the 1932 British murder trial of William Herbert Wallace, kicked off a new "Real-Life Cases" column for a quarterly mystery fiction magazine. McDade would contribute case write-ups for the next five years, skipping only one issue in the sequence. This inaugural column included a brief bibliography of books, articles, and novels based on the case; this conceit would often appear in future columns.

McDade, Thomas M. “Homicide and Other Investigations.” In The Mystery Writer's Handbook, edited by Lawrence Treat, 77-92. Cincinnati: Writer's Digest Books, 1982.

Guidance for writers of mystery fiction on police investigation practices and forensic science. While McDade acknowledges that some liberties may be needed for dramatic effect (noting that a courtroom scene "in which the lawyers had to follow the real rules of evidence would be a dreadful bore" (p.10)), McDade provides practical advice on procedure and terminology, encouraging authors to be as realistic as possible.

McDade, T.M. “Crime Hunt.” Armchair Detective 15, no. 1 (Winter 1982): 26-28. Examines the Roger Tichborne affair, a notorious case in the United Kingdom where a man was convicted of impersonating an heir who had been presumed lost at sea. The civil and criminal trials were both incredibly lengthy for the era and relied on eyewitness identification.

McDade, T.M. “Crime Hunt.” Armchair Detective 15, no. 2 (Spring 1982): 150-53. McDade's contribution to this column was an editorial note, calling back to his first Armchair Detective column on William Herbert Wallace. The remainder of the text is a new theory on the Wallace murder by British author Jonathan Goodman, who would later publish several McDade essays in his anthologies. 
McDade, T.M. “Crime Hunt: The Hiss Case.” Armchair Detective 15, no. 3 (Summer 1982): 274-75.

Revisits the case of Alger Hiss, accused of espionage during the House Un-American Activities Committee investigation. Although the statute of limitations had passed by the time the accusation became public, Hiss was convicted of perjury after denying the accusations under oath.

McDade, T.M. "Crime Hunt: The Lindbergh Kidnapping." Armchair Detective 15, no. 4 (Fall 1982): 367-69.

Fifty years after the kidnapping and murder of Charles Lindbergh's baby boy, McDade reexamines the evidence against Bruno Richard Hauptmann. The column was sparked by "revisionist" (p.369) books and articles that questioned the guilt of the convicted man, although McDade found them unconvincing in light of the weighty circumstantial evidence.

McDade, T.M. “Jimson's Folly.” Ellery Queen's Mystery Magazine 80, no. 5 (October 1982): 73-79.

Another rare fiction work appeared late in McDade's career, more than three decades after the same magazine published his first short story. The narrator explores the history of the previous owner and neighbors of his family's farm, discovering the key to a decades-old unsolved disappearance in the process.

McDade, T.M. "Cases on File: Take the Money and Run-Where?" Alfred Hitchcock's Mystery Magazine 27, no. 12 (November 1982): 55-59.

Inspired by an acquaintance's question about where criminals could safely relocate, McDade reviews the then-current state of extradition law, providing a list of the 65 countries that did not have extradition agreements with the United States. Includes a discussion of extradition laws back to ancient Egypt and then explores some cases of extralegal renditions from the 19th and 20th centuries. Given courts' willingness to uphold even questionably legal returns, McDade's ultimate advice was to remain in the United States and assume a new identity instead.

McDade, Thomas M. “A Pennyworth of Murder." In The Pleasures of Murder, edited by Jonathan Goodman, 100-07. London: Allison and Busby, 1983.

A reprint of 1950s' Gallows Literature of the Streets, on early British trial broadside publications. Sadly, this version removes the eye-catching illustrations that were featured in The New Colophon.

McDade, T.M. "Crime Hunt: The Problem of Will West." Armchair Detective 16, no. 1 (Winter 1983): 84-85.

Subtitled "The Case that Doomed the Bertillon System of Identification," this column tells the strange story of two inmates at Leavenworth in 1903, who stunned prison officials by having identical names as well as Bertillon measurements. The Bertillon system, which predated the use of fingerprinting as a law enforcement method of identifying criminals, included 11 precise body measurements, for which the two Will Wests were a perfect match.

McDade, T.M. “Crime Hunt: The Rice Case." Armchair Detective 16, no. 2 (Spring 1983): 202-05.

The 1900 murder of William Marsh Rice, the founder of what became Rice University, was set into motion by a dispute over his late wife's ability to bequeath half his fortune under Texas community property laws. The complex story involved an unethical lawyer, a duplicitous household servant, a forged will, and a botched cremation plan. 
McDade, T.M. “Crime Hunt: The Leyra Case.” Armchair Detective 16, no. 3 (Summer 1983): 316-19.

The 1950 murder of an elderly Brooklyn couple cast suspicion on their adult son, Camilo Weslan Leyra, Jr. A series of trials, death sentences, appeals, and reversals for coerced confessions ultimately led him out the door of prison almost five years later.

McDade, T.M. “Crime Hunt: The Waite Case." Armchair Detective 16, no. 4 (Fall 1983): 437-39.

Erstwhile medical student Arthur Warren Waite married into a wealthy Michigan family in 1915 and quickly set about plotting their demise for inheritance money. He dispatched both of his in-laws within the span of a month, but his plan unraveled due to suspicions within his social circle.

McDade, T.M. "Crime Hunt: The Stielow Case." Armchair Detective 17, no. 1 (Winter 1984): 96-97.

A recently published book on wrongful convictions inspired McDade's review of one such case, Charles F. Stielow's 1915 conviction for murder. Stielow was a tenant farmer, accused of murdering the farm's owner and his housekeeper; eventually his death sentence was commuted after a media campaign regarding his innocence.

McDade, T.M. "Crime Hunt: Harvard and Homicide." Armchair Detective 17, no. 2 (Spring 1984): 214-17.

An accounting of fugitive Erich Muenter, ex-German instructor at Harvard suspected of poisoning his wife in 1906. Muenter disappeared after failing to collect on a life insurance policy, eventually resurfacing under the alias Frank Holt, a Ph.D. scholar from Cornell. Holt was arrested in 1915 after an eventful 36 hours, during which he planted a bomb at the U.S. Senate, mailed another bomb into the cargo hold of a ship bound for Europe, and then returned to New York for an assassination attempt on banker J.P. Morgan. Holt committed suicide in custody, the ship was saved, and former colleagues at Harvard helped police connect the dual identities.

McDade, T.M. "Crime Hunt: A Case of Circumstantial Evidence." Armchair Detective 17, no. 3 (Summer 1984): 323-24.

McDade notes that circumstantial evidence is often maligned for unreliability, but is sometimes stronger than direct evidence (particularly eyewitness accounts). This short piece illustrates the legal limitations on circumstantial evidence through the murder conviction of Josef Razezicz, a Lithuanian immigrant accused of planting a bomb in 1911.

McDade, T.M. "Crime Hunt: The Murder Case as a Source of Fiction." Armchair Detective 17, no. 4 (Fall 1984): 442-43.

At a friend's request, McDade tracked down the record of a criminal trial that her attorney father had defended, involving the 1918 robbery and murder of a subway ticket seller. He describes his process in locating news and records of the case, and notes that mining real-life trials is a popular source of inspiration for authors.

McDade, T.M. “Crime Hunt.” Armchair Detective 18, no. 2 (Spring 1985): 216-18. The column resumed after an unexplained one-time absence from the Winter 1985 issue (vol. 18, no. 1), the only gap in its five-year run. The featured investigation was triggered by the death of John H. Borden, a VIP guest at the 1932 Army-Navy football game, which led to the discovery of missing money. A rookie FBI agent uncovered not murder but an embezzlement scheme. 
McDade, T.M. "Crime Hunt: The Creasy Case." Armchair Detective 18, no. 3 (Summer 1985): 323-25.

McDade reached back to his law school days to recount a case featured in his 1931 student note. The death of Edith Lavoy by the gun of her fiancé William M. Creasy could have been a suicide or a murder; appeals centered on how the jury was instructed to presume one circumstance or the other.

McDade, T.M. “Crime Hunt: Father Schmidt, Murderer." Armchair Detective 18, no. 4 (Fall 1985): 421-24.

A particularly gruesome tale of Father Hans Schmidt, a German priest convicted in New York of killing and dismembering a female victim in 1913. He later admitted that his insanity defense was a ruse, intended to cover up the deceased's true cause of death: complications from an abortion.

McDade, T.M. "Crime Hunt: The Swope-Hyde Case." Armchair Detective 19, no. 1 (Winter 1986): 94-97.

Members of a large extended family in Missouri began to suffer mysterious illnesses and deaths. Son-in-law Dr. Bennett Clarke Hyde was indicted for the murders of several, but eventually beat the charges.

McDade, T.M. "Crime Hunt: The Murder of Mrs. Gresh.” Armchair Detective 19, no. 2 (Spring 1986): 142-44.

Teenage lovers plotted to kill the girl's mother in 1954, leaving her body in the bathtub and telling friends that she had run off to Florida with a man. Their love affair quickly unraveled as the trial drew near.

McDade, T.M. “Crime Hunt: Insurance and Murder." Armchair Detective 19, no. 3 (Summer 1986): 285-87.

McDade tackled "the life insurance delusion": cases of murderers caught out by the purchase and collection of life insurance policies on their victims.

McDade, T.M. “Crime Hunt: Poison." Armchair Detective 19, no. 4 (Fall 1986): 398-401.

Advice for mystery writers on realistically writing about murder by poisoning, drawing from several real-life cases in the United States and United Kingdom.

McDade, T.M. "Crime Hunt: The Disappearance of Eugenia Cedarholm.” Armchair Detective 20, no. 1 (Winter 1987): 32-33.

A young woman's 1927 disappearance was never fully solved, although her lover was eventually convicted. This would prove to be McDade's last column in the Armchair Detective, although, like its debut, its conclusion appeared with no editorial fanfare.

McDade, Thomas M. “Looking for Baby-Face.” In The Vintage Car Murders, edited by Jonathan Goodman, 96-105. London: W.H. Allen, 1988.

Detailed account of McDade's harrowing 1934 car chase/shootout with gangster "Baby Face" Nelson that killed Nelson and two FBI agents. Includes a photo of young agent McDade standing next to the car and reproductions of Nelson's "Wanted" poster and accomplice John Paul Chase's mugshot.

McDade, Thomas M. "Mr. Jekyll and Dr. Hyde?" In Medical Murders, edited by Jonathan Goodman, 210-20. New York: Carol, 1992. First published in 1991 by Judy Piatkus, London.

Reprint of the Winter 1986 Armchair Detective column on the Swope-Hyde Case. 
McDade, Thomas M. "Harvard and Homicide." In Masterpieces of Murder, edited by Jonathan Goodman, 405-18. New York: Carroll and Graf, 1992. First published in 1992 in Great Britain.

Reprint of the Spring 1984 Armchair Detective column on the Erich Muenter case, including a new brief biographical sketch as introduction and a facsimile of McDade's signature at the end. 